\title{
Organic N-fertilizer, rhizobacterial inoculation and fungal compost improve nutrient uptake, plant growth and the levels of vindoline, ajmalicine, vinblastine, catharanthine and total alkaloids in Catharanthus roseus $\mathrm{L}$.
}

\author{
Davood Hashemabadi ${ }^{1 *}$, Fatemeh Sabzevari ${ }^{1}$, Behzad Kaviani ${ }^{1}$, \\ Mohammad Hossein Ansari ${ }^{2}$ \\ ${ }^{1}$ Department of Horticulture, Rasht Branch \\ Islamic Azad University, Rasht, Iran \\ ${ }^{2}$ Department of Agronomy and Plant Breeding, Rasht Branch \\ Islamic Azad University, Rasht, Iran
}

\begin{abstract}
The aim of the study was to replace mineral fertilizers with organic and biological fertilizers to improve nutrient uptake, plant growth and the concentrations of some important secondary metabolites in periwinkle (Catharanthus roseus L.). Periwinkle plants were grown under different rates of $\mathrm{N}$ supply $\left(0,20\right.$ and $40 \mathrm{mg} \mathrm{kg}^{-1}$ soil) and biological treatments (Azospirillum, Azotobacter, Azospirillum plus Azotobacter, Azospirillum plus fungal compost, Azotobacter plus fungal compost, and fungal compost). The concentrations of pigments and nutrients were measured by spectrophotometry and flame photometry. Secondary metabolites were analyzed by high-performance liquid chromatography (HPLC). Data were recorded for plant growth and development parameters, nutrient uptake and some secondary metabolites of periwinkle plants. The results showed that the $\mathrm{N}$-fertilizer and biological treatments significantly improved most growth attributes and nutrient uptake and increased the concentrations of secondary metabolites as compared to the control. Maximum concentrations of root ajmalicine $\left(0.54 \mathrm{mg} \mathrm{g}^{-1} \mathrm{DW}\right)$, leaf vinblastine $\left(0.96 \mathrm{mg} \mathrm{g}^{-1} \mathrm{DW}\right)$ and root catharanthine $\left(2.38 \mathrm{mg} \mathrm{g}^{-1} \mathrm{DW}\right)$ were obtained from the treatment with Azospirillum under N-fertilizer at 20 and $40 \mathrm{mg} \mathrm{kg}^{-1}$ soil. Azotobacter along with fungal compost under $\mathrm{N}$-fertilizer at $40 \mathrm{mg} \mathrm{kg}^{-1}$ soil induced the maximum concentration of leaf vindoline (1.94 $\left.\mathrm{mg} \mathrm{g}^{-1} \mathrm{DW}\right)$. The highest concentration of root alkaloids $\left(1.11 \mathrm{mg} \mathrm{g}^{-1} \mathrm{DW}\right)$ was obtained from the treatment with compost under $40 \mathrm{mg} \mathrm{N} \mathrm{kg}^{-1}$ soil. Azospirillum, Azotobacter and fungal compost combined with the $\mathrm{N}$-fertilizer improved many morphological and nutrient characteristics. In conclusion, the growth and metabolism of $C$. roseus were significantly positively affected by the organic and biological fertilizers.
\end{abstract}

Keywords: nitrogen fertilizer, periwinkle, plant secondary metabolites, root inoculation, Vinca rosea

\section{INTRODUCTION}

Periwinkle (Catharanthus roseus L., synonym Vinca rosea, Lochnera rosea), belonging to the family Apocynaceae and native to Madagascar, is a tropical perennial plant that is cultivated for various purposes such as pharmaceuticals, cosmetics, condiments and spices. It is grown in many tropical and subtropical regions (Łata, 2007). This ornamental and medicinal plant produces

*Corresponding author. 
more than 100 monoterpenoid indole alkaloids, distributed in all parts of the plant, particularly the roots and leaves (Maloney et al., 1968). Three types of action of these compounds are important: anticancer (vincristine and vinblastine), diuretic (vindoline and catharanthine) and hypotensive (ajmalicine and serpentine) (Łata, 2007; Magnotta et al., 2006; Masidur Alam et al., 2012). Vincristine and vinblastine used in the treatment of leukemia and lymphomas are mainly found in the leaves, while ajmalicine, used as antihypertensive substances (to treat high blood sugar and high blood pressure), is present in the roots (Mishra et al., 2001; Łata, 2007). Vindoline, with diuretic properties, is also contained in the leaves (Łata, 2007).

Extensive use of chemical fertilizers is costly and creates environmental problems. Therefore, there has been a need to use environmentally friendly, sustainable, organic and biological fertilizers. The use of biological fertilizers containing plant growth promoting rhizobacteria (PGPR) instead of chemical fertilizers may improve plant growth and development through increased supply of plant nutrients and soil productivity (Karthikeyan et al., 2010). Positive effects of PGPR, such as Azospirillum and Azotobacter, on improving the yield and quality of some species have been reported by several researchers (Karlidag et al., 2007; Abdul Jaleel et al., 2007; Karthikeyan et al., 2009). Nitrogen fixing and phosphate solubilizing bacteria are among the most important biological fertilizers that improve plant nutrition by increasing $\mathrm{N}$ and $\mathrm{P}$ uptake and the production of plant growth regulators by plants (Karlidag et al., 2007; Abdul Jaleel et al., 2007). Stimulating effects of PGPR, N supply and fungal compost on plant secondary metabolites in medicinal plants have been demonstrated in some species (Matros et al., 2006; Karthikeyan et al., 2008, 2009; Khattak et al., 2011; Singh and Agrawal, 2015). Certain secondary metabolite pathways are induced by infection with PGPR (Abdul Jaleel et al., 2009; Karthikeyan et al., 2009).

The present study was undertaken to determine the growth promoting effects of root inoculation with Azospirillum and Azotobacter, and fungal compost as well as $\mathrm{N}$ supply on nutrient uptake, plant growth and development, and the concentrations of vindoline, ajmalicine, vinblastine, catharanthine and total alkaloids in Catharanthus roseus L., an important ornamental and medicinal species.

\section{MATERIAL AND METHODS}

\section{Source materials, cultivation bed and growth conditions}

A pot culture experiment was carried out under natural light in a greenhouse at $28-30^{\circ} \mathrm{C}$ and $14 \mathrm{~h}$ photoperiod. Healthy seeds of periwinkle (Catharanthus roseus L.) were obtained from Sabz Fanavar Co. The seeds were sown into plastic pots (15 cm height $\times 20 \mathrm{~cm}$ diameter) filled with $5 \mathrm{~kg}$ of a homogenous mixture of sandy loam soil along with an organic $\mathrm{N}$-fertilizer, biological fertilizers and fungal compost as experimental treatments. The concentrations of nutrients in the experimental soil and fungal compost were determined at the Soil and Plant Analysis laboratory prior to the experiment (Tabs 1 and 2). N, P and K were added to the soil prior to the experiment and during the plant growth period based on the fertilization condition of the experimental soil. Growing plantlets were kept free from weeds and irrigated as and when required.

\section{Treatments}

The seeds were treated with different concentrations of N-fertilizer, nitrogen-fixing rhizobacteria and fungal compost. The study was conducted with two experimental factors at three and seven levels, respectively, as follows: 1 . N-fertilizer $(0,20$ and $40 \mathrm{mg} \mathrm{kg}^{-1}$ soil); 2 . Nitrogen-fixing rhizobacteria and fungal compost (Azospirillum, Azotobacter, Azospirillum + Azotobacter, Azospirillum + fungal compost, Azotobacter + fungal compost, fungal compost and control). The fungal compost constituted $40 \%$ of the pot volume.

\section{Morphological, physiological and biochemical analyses}

\section{Determination of morphological characteristics}

After a period of 60 days, the following variables were recorded: plantlet height, node number, leaf number, root length, root volume, flower number and flower diameter. Root length, flower diameter and plantlet height were measured with a ruler.

Table 1. Physical and chemical characteristics of the soil used

\begin{tabular}{|c|c|c|c|c|c|c|c|c|c|c|c|}
\hline Sand & Silt & Clay & \multirow{2}{*}{$\begin{array}{c}\mathrm{EC} \\
\left(\mathrm{dS} \mathrm{m}^{-1}\right)\end{array}$} & \multirow{2}{*}{$\mathrm{pH}$} & \multirow{2}{*}{$\begin{array}{l}\mathrm{OC} \\
(\%)\end{array}$} & \multirow{2}{*}{$\begin{array}{l}\mathrm{N} \\
(\%)\end{array}$} & $\mathrm{P}$ & $\mathrm{K}$ & $\mathrm{Zn}$ & $\mathrm{Fe}$ & $\mathrm{Mn}$ \\
\hline & $(\%)$ & & & & & & \multicolumn{5}{|c|}{$\left(\mathrm{mg} \mathrm{kg}^{-1}\right)$} \\
\hline 27 & 43 & 30 & 0.69 & 7.1 & 0.8 & 0.08 & 11.7 & 176 & 0.64 & 4.4 & 7.12 \\
\hline
\end{tabular}


Table 2. Physico-chemical properties and elemental composition of the fungal compost and their detection method

\begin{tabular}{lcc}
\hline Parameters & Method & Fungal compost \\
\hline $\mathrm{pH}$ & pH meter & 7.43 \\
$\mathrm{EC}$ & Conductometer & 1.26 \\
Ash content $\left(\mathrm{g} \mathrm{kg}^{-1}\right)$ & Burning & 441 \\
Total OC $\left(\mathrm{g} \mathrm{kg}^{-1}\right)$ & Walkley black & 316 \\
Total OM $(\%)$ & Nitration & 49 \\
Total N $\left(\mathrm{g} \mathrm{kg}^{-1}\right)$ & Kjeldahl & 28.3 \\
Total P $\left(\mathrm{g} \mathrm{kg}^{-1}\right)$ & Olsen & 13.48 \\
Total K $\left(\mathrm{g} \mathrm{kg}^{-1}\right)$ & Flame photometry & 13.7 \\
$\mathrm{C}: \mathrm{N} \mathrm{ratio}$ & - & 11.3 \\
$\mathrm{Cu}\left(\mathrm{mg} \mathrm{kg}^{-1}\right)$ & Atomic & 164.8 \\
$\mathrm{Fe}\left(\mathrm{mg} \mathrm{kg}^{-1}\right)$ & Atomic & 496.6 \\
$\mathrm{Mn}\left(\mathrm{mg} \mathrm{kg}^{-1}\right)$ & Atomic & 248.7 \\
$\mathrm{Zn}\left(\mathrm{mg} \mathrm{kg}^{-1}\right)$ & Atomic & 369 \\
\hline
\end{tabular}

The number of organs was counted with a naked eye in intact plants. To measure the volume of the roots, first, the roots were removed from the soil and washed thoroughly under running tap water. Water was poured into a graduated cylinder to a certain level and the roots were immersed up to the crown in the cylinder. The increase in the level of water represented root volume.

\section{Estimation of aerial and root dry matter percentage}

Whole shoots of the plants were harvested at maturity and were oven-dried at $70^{\circ} \mathrm{C}$ for $24 \mathrm{~h}$ to determine their dry weight. The roots of the plants were cut away from the crown at maturity and were oven-dried at $70^{\circ} \mathrm{C}$ for $24 \mathrm{~h}$ to determine their dry weight. The aerial and root dry matter percentage was calculated as follows:

$$
\text { Aerial and root dry matter percentage }=\frac{\text { Dry weight }}{\text { Fresh weight }} \times 100
$$

\section{Estimation of leaf total chlorophyll}

To measure the chlorophyll content of the leaves, $0.5 \mathrm{~g}$ of leaves were weighed using digital scales, placed in a solution containing $80 \%$ acetone and distilled water, and then thoroughly ground in a porcelain mortar. The prepared solution was passed through filter paper and the filtered solution was made up to a volume of $50 \mathrm{ml}$ with $80 \%$ acetone and distilled water. Chlorophyll content was calculated according to the following equation (Mazumdar and Majumder, 2003):

$$
\text { Total chlorophyll content }=7.12\left(\mathrm{~A}_{660}\right)+16.8\left(\mathrm{~A}_{642.5}\right)
$$

where; ' $A$ ' is light absorbance at wavelengths of 660 and $642.5 \mathrm{~nm}$.

\section{Estimation of petal anthocyanin}

A $0.5 \mathrm{~g}$ sample of a fresh petal during the flowering period was ground in liquid nitrogen, using a mortar and pestle. Acidic methanol (pure methanol $+\mathrm{HCl}$ ) was added to the ground petal to obtain an extract. The anthocyanin concentration was calculated as follows (Singh et al. 2004):

Anthocyanin concentration (mg $\left.100 \mathrm{~g}^{-1} \mathrm{FW}\right)=\frac{\mathrm{e} \times \mathrm{b} \times \mathrm{c}}{\mathrm{d} \times \mathrm{a}} \times 100$

where: 'e' is specimen weight, 'b' is specimen volume for measurement, 'c' is whole made solution volume, ' $d$ ' is volume of specimen taken, and ' $a$ ' is light absorbance at a wavelength of $535 \mathrm{~nm}$.

\section{Estimation of N, $P$ and $K$ content}

For macro- and microelement analyses, the youngest mature leaves on the shoots were collected, dried and ground. To measure N, P and K, $0.3 \mathrm{~g}$ of leaves dried at a temperature of $75^{\circ} \mathrm{C}$ for $24 \mathrm{~h}$ were placed in $3 \mathrm{ml}$ of mixed acids $(100 \mathrm{ml}$ sulfuric acid + $6 \mathrm{~g}$ of salicylic acid, and $18 \mathrm{ml}$ distilled water) and digestion was carried out on a heater using $\mathrm{H}_{2} \mathrm{O}_{2}$. The obtained solution was filtered and the final volume was brought to $50 \mathrm{ml}$ with distilled water. This solution was used to estimate N, P and K. Total nitrogen $(\mathrm{N})$ concentration of leaf blades was determined by the Kjeldahl method (AOAC 1970). The concentration of phosphorus was measured by spectrophotometry. Potassium content was calculated using flame photometry.

\section{Estimation of N, $P$ and $K$ uptake from soil}

To estimate N, P and K uptake, we need to know the concentration of these elements in the plant and the 
plant's dry weight. N, P and K uptake from soil was calculated according to the following equation:

Element concentration in plant $\times$ plant dry weight 100

\section{Estimation of total alkaloid content in roots}

The total alkaloid content in roots was estimated as described by Afaq et al. (1994). The roots were dried using an oven at $80^{\circ} \mathrm{C}$ for $24 \mathrm{~h}$. The dried roots were powdered and passed through a 72 mesh screen. A $500 \mathrm{mg}$ sample of root powder was transferred into a $100 \mathrm{ml}$ round bottom flask. A known volume of ethyl alcohol was added to this flask and refluxed for $6 \mathrm{~h}$. Then, it was filtered through a Whatman No. 1 filter paper. $50 \mathrm{ml}$ of dilute $\mathrm{HCl}$ was added to the filtered solution. Thereafter, it was transferred into a separating funnel, to which $50 \mathrm{ml}$ of diethyl ether was added. This solution was shaken for $20 \mathrm{~min}$. The upper layer was discarded and the lower water layer was decanted into a beaker and made basic by adding an ammonia solution. The decanted content was transferred into a separating funnel with $50 \mathrm{ml}$ diethyl ether layer and was decanted. Anhydrous sodium carbonate was added to the decanted solution. The mixture was again decanted in a preweighed dry porcelain dish and was heat-evaporated until dry and weighed again (Masidur Alam et al., 2012). The total alkaloid content (\%) was obtained using the following formula:

$$
\frac{W_{A}-W_{E}}{W_{R}} \times 100
$$

where, $\mathrm{W}_{\mathrm{A}}$ is weight of dry porcelain dish and dry alkaloid residue after evaporation $(\mathrm{g}) ; \mathrm{W}_{\mathrm{E}}$ is weight of empty, dry porcelain dish ( $\mathrm{g}$ ); and $\mathrm{W}_{\mathrm{R}}$ is weight of the tissue powder ( $\mathrm{g}$ ).

Estimation of vindoline, ajmalicine, catharanthine, vinblastine and vincristine

Vindoline, ajmalicine, catharanthine, vinblastine and vincristine were extracted from $C$. roseus according to Luo et al. (2005), with slight changes. The alkaloids were extracted with hot methanol (100\%) from dry plant powder. The alkaloid extract was filtered and analyzed by highperformance liquid chromatography (HPLC). The detailed method was as follows: these four kinds of alkaloids were separated on a Diamonsil C18 column $(250 \mathrm{~mm} \times 4.6 \mathrm{~mm}, 5 \mu \mathrm{m})$, using $380 \mathrm{~mL}$ solution A [water: diethylamide $=986: 14(\mathrm{v} / \mathrm{v}), \mathrm{pH}$ 7.2] combined with $620 \mathrm{~mL}$ solution $\mathrm{B}$ [methanol: acetonitrile $=4: 1(\mathrm{v} / \mathrm{v})]$ as the mobile phase. The detection was performed at a flow rate of $1.5 \mathrm{~mL}$ $\mathrm{min}^{-1}$ and a wavelength of $220 \mathrm{~nm}$ within $40 \mathrm{~min}$.

\section{Experimental design and statistical analysis}

The experiment was conducted according to a completely randomized factorial design with three replications. Statistical analyses were performed by using Microsoft Excel 2013 and Statistical Package for Social Sciences (SPSS) v. 16.0. The analysis of variance (ANOVA) procedure for a factorial experiment was used to test for significant effects of treatments, followed by an LSD test and the use of LS means for comparisons of the means of different treatments.

\section{RESULTS AND DISCUSSION}

\section{Effect of treatments on morphological characteristics}

The effect of bacterial treatments was significant on most morphological characteristics, regardless of N-supply (Tab. 3). However, there was a level of N-supply among the treatments that induced the highest values of these parameters, but the differences were not significant between the 'with' and 'without' applications of N-fertilizer. Azospirillum plus Azotobacter under $40 \mathrm{mg} \mathrm{N} \mathrm{kg}{ }^{-1}$ soil resulted in the greatest plant height $(41.43 \mathrm{~cm}$ per plant), surpassing the control by $19.80 \mathrm{~cm}$ per plant. According to Table 3, very tall plants (33 $-38 \mathrm{~cm}$ per plant) were observed in the treatments containing Azospirillum, Azotobacter and fungal compost without and/or with $20 \mathrm{mg} \mathrm{N} \mathrm{kg}^{-1}$ soil. The application of Azotobacter along with fungal compost, and Azospirillum along with fungal compost, both under $40 \mathrm{mg} \mathrm{N} \mathrm{kg}^{-1}$ soil, resulted in the largest number of nodes (15.00 per plant) and leaves (149.80 per plant) in comparison with the control, which showed the lowest values (9.13 and 28.33, respectively) (Tab. 3). Fungal compost and $\mathrm{N}$-fertilizer at $20 \mathrm{mg} \mathrm{kg}{ }^{-1}$ soil was the best combination for increasing root length $(32.30 \mathrm{~cm})$. Azotobacter under $20 \mathrm{mg} \mathrm{N} \mathrm{kg}^{-1}$ soil was the next best treatment regarding root length. The control plants produced the shortest roots $(21.77 \mathrm{~cm})$ (Tab. 3). Plants grown in the medium containing Azotobacter plus fungal compost produced the highest number of flowers (27.98 per plant) under $\mathrm{N}$-supply of $20 \mathrm{mg} \mathrm{kg}^{-1}$ soil. The control plants produced the lowest number of flowers (3.13) (Tab. 3). Maximum and minimum flower diameters (35.65 and $27.46 \mathrm{~mm}$ per plant) were measured in the plants grown in the media without the $\mathrm{N}$-fertilizer. Fungal compost induced the maximum and Azospirillum along with fungal compost induced the minimum flower diameter (Tab. 3). Azospirillum 


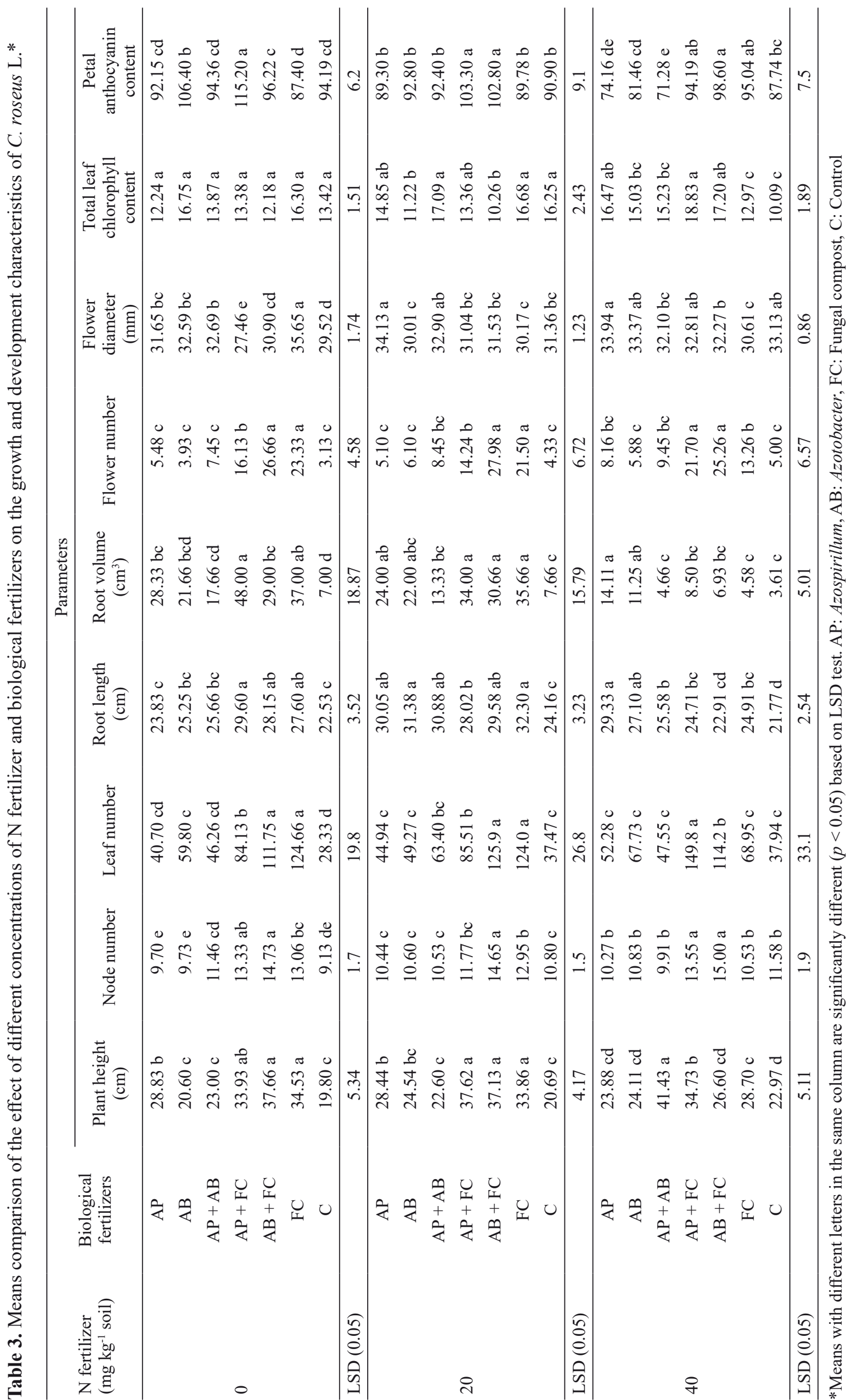


along with fungal compost without $\mathrm{N}$-fertilizer resulted in the highest root volume $\left(48.00 \mathrm{~cm}^{3}\right.$ per plant) compared to the control, which showed the lowest value (3.61 $\mathrm{cm}^{3}$ per plant) (Tab. 3).

The current study reveals that there was significant improvement in the morphological characteristics as a result of the application of PGPR and fungal compost. Similar results had been reported earlier in Catharanthus roseus L. and some other medicinal plants (Siddiqui, 2004; Thosar et al., 2005; Karthikeyan et al., 2010). The stimulating effect of PGPR on plant growth can be due to the increased supply of plant nutrients, particularly by the $\mathrm{N}_{2}$ fixation ability, and greater soil productivity, especially by the phosphate solubilizing capacity (O'Connell, 1992; Karthikeyan et al., 2010). PGPR can also promote plant growth through the production of plant growth regulators, particularly auxins and gibberellins (Karthikeyan et al., 2009, 2010). It is important to note that the increase in growth characteristics observed following inoculation with PGPR has been found to manifest itself in an increase in root number, root length and root biomass, which in turn can enhance mineral uptake (NPK) in plants (Khalid et al., 2004; Karthikeyan et al., 2009).

\section{Effect of treatments on plant biomass}

Statistically significant differences were found between the means for plant biomass and treatments. The maximum value of the biomass of aerial parts (14.84\%) was produced by Azotobacter without $\mathrm{N}$-supply in comparison with the control, which showed the minimum value (5.39\%) (Tab. 3). On the other hand, of the various organic and biological fertilizer treatments, fungal compost under $\mathrm{N}$-fertilizer at $20 \mathrm{mg} \mathrm{kg}^{-1}$ soil induced the maximum value of root biomass (13.73\%) in comparison with the control, which showed the minimum value (4.50\%) (Tab. 3).

Our findings demonstrated that plant biomass was increased when PGPR or fungal compost were applied separately. Contrary to this finding, earlier reports on Catharanthus roseus L. and some other species had shown that combined inoculation with PGPR increased dry matter content (Algawadi and Gaur, 1992; Cakmakci et al., 2007; Karlidag et al., 2007; Karthikeyan et al., 2010). This difference may be due to the type of plant species and applied bacterial strains. Lata (2007) showed that the highest plant biomass in Catharanthus roseus $\mathrm{L}$. was obtained at $200 \mathrm{mg} \mathrm{N} \mathrm{dm}^{-3}$ in the substrate. Plants with a vigorous growth and the highest biomass contained 2.9-3.0\% nitrogen in the dry matter of the leaves (Lata, 2007). The stimulatory effect of PGPR on plant biomass has been attributed to the fixation of atmospheric nitrogen, phosphate solubilizing capacity and the production of plant growth regulators (PGRs) (Vessey, 2003; Cakmakci et al., 2007; Karlidag et al., 2007).

\section{Effect of treatments on leaf and petal pigments}

Total chlorophyll and anthocyanin contents were significantly increased under the bacterial and fungal treatments. Analysis of variance revealed that the amounts of chlorophyll and anthocyanins were changed by the organic and biological treatments, separately or in combination. Azospirillum along with fungal compost under $\mathrm{N}$-fertilizer at $40 \mathrm{mg}$ $\mathrm{kg}^{-1}$ soil followed by Azotobacter along with fungal compost under $\mathrm{N}$-fertilizer at $40 \mathrm{mg} \mathrm{kg}^{-1}$ soil and Azospirillum plus Azotobacter under $\mathrm{N}$-fertilizer at $20 \mathrm{mg} \mathrm{kg}^{-1}$ soil increased the amount of total chlorophyll to the highest extent. The lowest chlorophyll content was calculated in the control plants (Tab. 3). Azospirillum plus Azotobacter under $40 \mathrm{mg} \mathrm{N} \mathrm{kg}{ }^{-1}$ soil caused a significant reduction in the production of anthocyanins. Azospirillum along with fungal compost without $\mathrm{N}$-fertilizer significantly stimulated the production of anthocyanins (Tab. 3).

Different rates of $\mathrm{N}$ supply significantly increased the amounts of photosynthetic pigments. Nitrogen is a major component of the chlorophyll structure. Singh and Agrawal (2015) had reported an increase in chlorophyll content of Catharanthus roseus $\mathrm{L}$. with $\mathrm{N}$ supply, which may be ascribed to enhanced uptake of N. Shangguan et al. (2000) reported a reduction in total chlorophyll content caused by nitrogen deficiency. High soil nitrogen supply enhanced the absorption rate of leaves due to increased chlorophyll content (Singh and Agrawal, 2015). A similar finding had been reported by Zhao et al. (2010). PGPR can have an important role in increasing the amount of nitrogen through fixation of atmospheric nitrogen.

\section{Effect of treatments on uptake and concentration of macro-nutrients}

The ANOVA test revealed a significant effect of the treatments and their combinations on the uptake and concentration of $\mathrm{N}, \mathrm{P}$ and $\mathrm{K}$. Based on Table 4 , the maximum concentrations of $\mathrm{N}, \mathrm{P}$ and $\mathrm{K}$ were obtained in the plants treated with rhizobacteria and fungal compost without the application of $\mathrm{N}$-fertilizer. The maximum concentrations of $\mathrm{N}$ (3.94\%), P (0.16\%) and K (15.27\%) were induced 


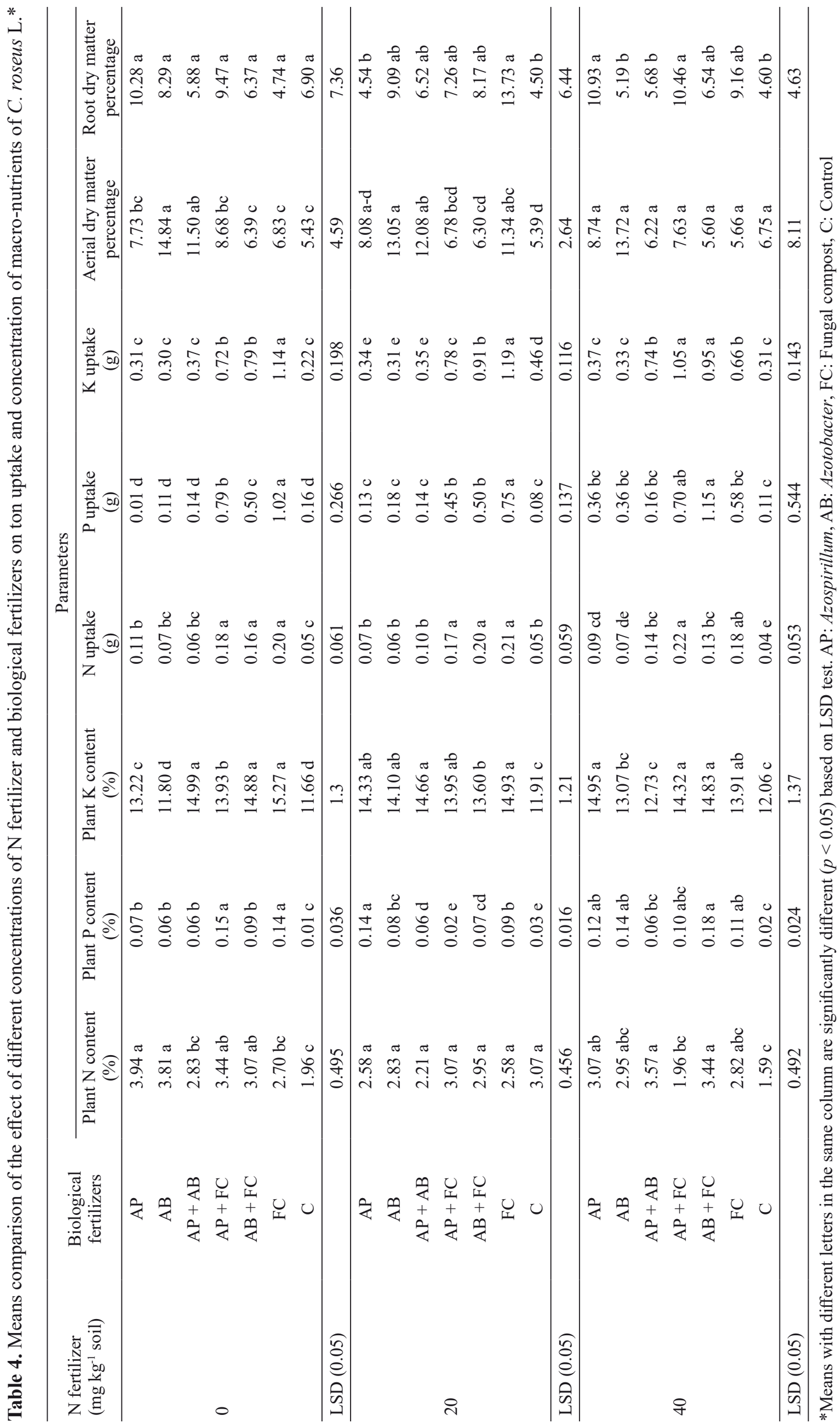


with Azospirillum, Azospirillum along with fungal compost, and fungal compost. The minimum concentrations of $\mathrm{N}(1.59 \%), \mathrm{P}(0.01 \%)$ and $\mathrm{K}$ $(11.71 \%)$ were produced in the control plants. Compost notably enhanced the uptake of $\mathrm{N}$, $\mathrm{P}$ and $\mathrm{K}$ (Tab. 4). The highest uptake of $\mathrm{N}(0.22$ and $0.21 \mathrm{~g}$ ) was shown by the plants treated with Azospirillum along with fungal compost, and fungal compost under $\mathrm{N}$-fertilizer at 40 and $20 \mathrm{mg} \mathrm{kg}^{-1}$ soil, respectively (Tab. 4 . This amount is 5 times higher than the uptake of $\mathrm{N}$ in the control plants. The highest uptake of $\mathrm{P}(1.15 \mathrm{~g})$ was obtained from the plants treated with Azotobacter along with fungal compost under $\mathrm{N}$-fertilizer at $40 \mathrm{mg} \mathrm{kg}^{-1}$ soil, surpassing the control by $0.08 \mathrm{~g}$ (Tab. 4). The maximum uptake of $\mathrm{K}(1.19 \mathrm{~g})$ was calculated for the plants treated solely with fungal compost. The minimum uptake of $\mathrm{K}(0.22 \mathrm{~g})$ was shown by the control plants (Tab. 4).

Mineral nutrition is one of the most important elements of field cultivation. Nitrogen is the main yield-determining factor under field conditions (Łata, 2007). Catharanthus roseus L., as an alkaloidrich species, can be classified as a high $\mathrm{N}$ demanding plant (Lata, 2007). The current study showed the importance of fungal compost, PGPR and N supply for the uptake of N, P and K from soil. The amounts of these elements in plants were also high with the application of compost. $\mathrm{N}$ supply had an important role in determining the amounts of $\mathrm{N}, \mathrm{P}$ and $\mathrm{K}$ in plants but not for the uptake of these elements. Similar to our findings, Łata (2007) showed that an increased $\mathrm{N}$ supply stimulated $\mathrm{K}$ and $\mathrm{P}$ uptake by Catharanthus roseus L. Earlier reports had shown that fungal compost was the best for Catharanthus roseus L. production (Khattak et al., 2011). A study by Karthikeyan et al. (2010) on Catharanthus roseus $\mathrm{L}$. revealed that the maximum $\mathrm{N}, \mathrm{P}$ and $\mathrm{K}$ content was obtained from treatments with PGPR. The higher N, P and K content in PGPR treatments may have resulted from the fixation of atmospheric nitrogen and P-solubilizing and absorption ability of these rhizobacteria and fungal compost (Cakmakci et al., 2007; Karlidag et al., 2007; Karthikeyan et al., 2010). Similar reports on the role of PGPR in the enhancement of plant nutrient elements have been presented (Shen et al., 2004).

\section{Effect of treatments on secondary metabolites}

The results showed that all the measured secondary metabolites of Catharanthus roseus L. were significantly increased by the bacterial and fungal treatments (Tab. 5). There was a significant increase in the concentration of root ajmalicine $\left(0.54 \mathrm{mg} \mathrm{g}^{-1}\right.$ DW) and leaf vinblastine $\left(0.96 \mathrm{mg} \mathrm{g}^{-1} \mathrm{DW}\right)$ with the application of Azospirillum under $\mathrm{N}$-fertilizer at $20 \mathrm{mg} \mathrm{kg}^{-1}$ soil. The concentration of leaf vinblastine $\left(0.95 \mathrm{mg} \mathrm{g}^{-1} \mathrm{DW}\right)$ was high through the application of fungal compost under $\mathrm{N}$-fertilizer at $40 \mathrm{mg} \mathrm{g}^{-1}$ soil. The concentrations of root ajmalicine $(0.24$ $\left.\mathrm{mg} \mathrm{g}^{-1} \mathrm{DW}\right)$ and leaf vinblastine $\left(0.64 \mathrm{mg} \mathrm{g}^{-1} \mathrm{DW}\right)$ were the lowest in the control plants (Tab. 5). The highest root catharanthine content $\left(2.39 \mathrm{mg} \mathrm{g}^{-1} \mathrm{DW}\right)$ was obtained in the treatment with Azospirillum under N-supply at $40 \mathrm{mg} \mathrm{kg}^{-1}$ soil followed by the treatment with Azotobacter along with fungal compost without $\mathrm{N}$-supply (2.35 $\left.\mathrm{mg} \mathrm{g}^{-1} \mathrm{DW}\right)$. The lowest root catharanthine content $\left(0.71 \mathrm{mg} \mathrm{g}^{-1} \mathrm{DW}\right)$ was obtained from the control plants. Azotobacter plus fungal compost under N-supply at $40 \mathrm{mg}$ $\mathrm{kg}^{-1}$ soil produced the maximum leaf vindoline content (1.94 $\left.\mathrm{mg} \mathrm{g}^{-1} \mathrm{DW}\right)$. The control plants had the minimum vindoline content $\left(1.05 \mathrm{mg} \mathrm{g}^{-1} \mathrm{DW}\right)$. Azospirillum plus Azotobacter under $20 \mathrm{mg} \mathrm{N} \mathrm{kg}^{-1}$ soil caused the maximum increase in the total root alkaloid content ( $0.93 \mathrm{mg} \mathrm{g}^{-1}$ D.W.). Azospirillum plus fungal compost and Azotobacter, both under $\mathrm{N}$-fertilizer at $40 \mathrm{mg} \mathrm{kg}^{-1}$ soil, and also Azotobacter plus fungal compost caused the production of total alkaloids of more than $0.90 \mathrm{mg} \mathrm{g}^{-1} \mathrm{DW}$ (Tab. 5). Compared with the treatments mentioned above, the plants grown in the cultivation bed without bacterial and fungal treatments produced the lowest amount of total root alkaloids $\left(0.72 \mathrm{mg} \mathrm{g}^{-1} \mathrm{DW}\right)$. The results of the ANOVA test showed that the concentrations of vindoline, ajmalicine, vinblastine, catharanthine and total alkaloids varied due to the organic and biological fertilizers and their interaction.

Nitrogen is a constituent of alkaloids and plays an important role in their synthesis (Lata, 2007). Also, P has the greatest influence on alkaloid synthesis by Catharanthus roseus L. (Lata, 2007). The application of Azospirillum resulted in the maximum concentrations of ajmalicine, vinblastine, catharanthine and total alkaloids. Similar significant increases in the concentration of alkaloids have been observed in plants exposed to various PGPR, particularly Azospirillum (Thosar et al., 2005; Karthikeyan et al., 2009, 2010). It is likely that with the use of PGPR the amount of growth regulators is increased, which causes an increase in the concentration of alkaloids. Our results are in agreement with those of other researchers (Karthikeyan et al., 2010). Corresponding to our results, a positively significant effect of PGPR on the alkaloid content of Catharanthus roseus L. 
Table 5. Means comparison of the effect of different concentrations of $\mathrm{N}$ fertilizer and biological fertilizers on the secondary metabolites of $C$. roseus L.*

\begin{tabular}{|c|c|c|c|c|c|c|}
\hline \multirow[b]{2}{*}{$\begin{array}{l}\mathrm{N} \text { fertilizer } \\
\left(\mathrm{mg} \mathrm{kg}^{-1} \text { soil }\right)\end{array}$} & \multirow[b]{2}{*}{$\begin{array}{l}\text { Biological } \\
\text { fertilizers }\end{array}$} & \multicolumn{5}{|c|}{ Parameters } \\
\hline & & $\begin{array}{l}\text { Leaf vindoline } \\
\left(\mathrm{mg} \mathrm{g}^{-1} \mathrm{DW}\right)\end{array}$ & $\begin{array}{l}\text { Leaf vinblastine } \\
\quad\left(\mathrm{mg} \mathrm{g}^{-1} \mathrm{DW}\right)\end{array}$ & $\begin{array}{l}\text { Root ajmalicine } \\
\left(\mathrm{mg} \mathrm{g}^{-1} \mathrm{DW}\right)\end{array}$ & $\begin{array}{c}\text { Root } \\
\text { catharanthine } \\
\left(\mathrm{mg} \mathrm{g}^{-1} \mathrm{DW}\right)\end{array}$ & $\begin{array}{c}\text { Total root } \\
\text { alkaloids } \\
\left(\mathrm{mg} \mathrm{g}^{-1} \mathrm{DW}\right)\end{array}$ \\
\hline \multirow{7}{*}{0} & $\mathrm{AP}$ & $1.34 \mathrm{bc}$ & 0.67 & 0.28 & $1.42 \mathrm{~b}$ & $0.78 \mathrm{a}$ \\
\hline & $\mathrm{AB}$ & $1.32 \mathrm{bc}$ & 0.66 & 0.28 & $1.36 \mathrm{~b}$ & $0.77 \mathrm{a}$ \\
\hline & $\mathrm{AP}+\mathrm{AB}$ & $1.64 \mathrm{a}$ & 0.7 & 0.29 & $1.26 \mathrm{bc}$ & $0.81 \mathrm{a}$ \\
\hline & $\mathrm{AP}+\mathrm{FC}$ & $1.53 \mathrm{ab}$ & 0.72 & 0.3 & $2.16 \mathrm{a}$ & $0.84 \mathrm{a}$ \\
\hline & $\mathrm{AB}+\mathrm{FC}$ & $1.38 \mathrm{abc}$ & 0.67 & 0.28 & $2.35 \mathrm{a}$ & $0.78 \mathrm{a}$ \\
\hline & $\mathrm{FC}$ & $1.25 \mathrm{bc}$ & 0.63 & 0.26 & $1.39 \mathrm{~b}$ & $0.74 \mathrm{a}$ \\
\hline & $\mathrm{C}$ & $1.20 \mathrm{c}$ & 0.73 & 0.31 & $0.87 \mathrm{c}$ & $0.85 \mathrm{a}$ \\
\hline \multicolumn{2}{|l|}{$\operatorname{LSD}(0.05)$} & 0.305 & 0.049 & 0.056 & 0.683 & 0.259 \\
\hline \multirow{7}{*}{20} & $\mathrm{AP}$ & $1.55 \mathrm{abc}$ & $0.96 \mathrm{a}$ & $0.54 \mathrm{a}$ & $2.28 \mathrm{a}$ & $0.85 a b c$ \\
\hline & $\mathrm{AB}$ & $1.38 \mathrm{bc}$ & $0.68 \mathrm{~cd}$ & $0.28 \mathrm{bc}$ & $1.23 \mathrm{~b}$ & $0.79 \mathrm{c}$ \\
\hline & $\mathrm{AP}+\mathrm{AB}$ & $1.80 \mathrm{a}$ & $0.80 \mathrm{~b}$ & $0.34 \mathrm{~b}$ & $1.18 \mathrm{~b}$ & $0.93 \mathrm{a}$ \\
\hline & $\mathrm{AP}+\mathrm{FC}$ & $1.65 \mathrm{ab}$ & $0.76 \mathrm{bc}$ & $0.32 \mathrm{bc}$ & $2.23 \mathrm{a}$ & $0.88 \mathrm{abc}$ \\
\hline & $\mathrm{AB}+\mathrm{FC}$ & $1.59 \mathrm{abc}$ & $0.77 \mathrm{bc}$ & $0.32 b c$ & $1.13 \mathrm{~b}$ & $0.90 \mathrm{ab}$ \\
\hline & $\mathrm{FC}$ & $1.32 \mathrm{~cd}$ & $0.71 \mathrm{bcd}$ & $0.30 \mathrm{bc}$ & $2.38 \mathrm{a}$ & $0.83 \mathrm{bc}$ \\
\hline & $\mathrm{C}$ & $1.05 \mathrm{~d}$ & $0.64 \mathrm{~d}$ & $0.24 \mathrm{c}$ & $1.15 \mathrm{~b}$ & $0.72 \mathrm{c}$ \\
\hline \multicolumn{2}{|l|}{$\operatorname{LSD}(0.05)$} & 0.417 & 0.121 & 0.033 & 0.761 & 0.078 \\
\hline \multirow{7}{*}{40} & $\mathrm{AP}$ & $1.41 \mathrm{ab}$ & $0.68 \mathrm{~cd}$ & $0.28 \mathrm{c}$ & $2.38 \mathrm{a}$ & $0.79 \mathrm{bc}$ \\
\hline & $\mathrm{AB}$ & $1.69 \mathrm{ab}$ & $0.80 \mathrm{~b}$ & $0.33 \mathrm{~b}$ & $2.13 \mathrm{ab}$ & $0.93 \mathrm{~b}$ \\
\hline & $\mathrm{AP}+\mathrm{AB}$ & $1.50 \mathrm{ab}$ & $0.71 \mathrm{bcd}$ & $0.30 \mathrm{bc}$ & $2.01 \mathrm{ab}$ & $0.83 \mathrm{bc}$ \\
\hline & $\mathrm{AP}+\mathrm{FC}$ & $1.75 \mathrm{ab}$ & $0.79 \mathrm{bc}$ & $0.33 \mathrm{~b}$ & $2.03 \mathrm{ab}$ & $0.92 \mathrm{bc}$ \\
\hline & $\mathrm{AB}+\mathrm{FC}$ & $1.94 \mathrm{a}$ & $0.65 \mathrm{~d}$ & $0.27 \mathrm{c}$ & $1.53 \mathrm{~b}$ & $0.75 \mathrm{c}$ \\
\hline & $\mathrm{FC}$ & $1.38 \mathrm{ab}$ & $0.95 \mathrm{a}$ & $0.40 \mathrm{a}$ & $0.85 \mathrm{c}$ & $1.11 \mathrm{a}$ \\
\hline & $\mathrm{C}$ & $1.17 \mathrm{~b}$ & $0.67 \mathrm{~d}$ & $0.27 \mathrm{c}$ & $0.71 \mathrm{c}$ & $0.80 \mathrm{bc}$ \\
\hline LSD $(0.05)$ & & 0.619 & 0.115 & 0.038 & 0.651 & 0.164 \\
\hline
\end{tabular}

*Means with different letters in the same column are significantly different $(p<0.05)$ based on LSD test. AP: Azospirillum, AB: Azotobacter, FC: Fungal compost, C: Control

plants was reported by Karthikeyan et al. (2009, 2010), Attia and Saad (2001) and Abdul Jaleel et al. (2007). The alkaloid content of Catharanthus roseus L. was significantly increased by the bacterial treatment (Karthikeyan et al., 2010). Similar reports on the role of PGPR in the induction of secondary metabolite synthesis, particularly of alkaloids, had been presented earlier (Khalid et al., 2004; Karthikeyan et al., 2010).

\section{CONCLUSIONS}

1. Application of organic fertilizers and plant growth-promoting rhizobacteria (PGPR) and fungal compost as biofertilizers instead of chemical fertilizers is a promising approach to the growth and development of medicinal species.
2. PGPR promote plant growth by triggering the production of PGRs and facilitate the uptake of nutrients from the soil. Fungi enhance nutrient uptake, especially of phosphate.

3. PGPR and fungal compost stimulate the synthesis and accumulation of secondary metabolites in plants.

4. The use of suitable levels of organic $\mathrm{N}$-fertilizers, PGPR and fungal compost can increase the amounts of pigments, improve the morphological and physiological characteristics, and increase the concentration of nutrient elements and some secondary metabolites in C. roseus $\mathrm{L}$.

\section{ACKNOWLEDGEMENT}

The authors are thankful to the Islamic Azad University, Rasht Branch for providing the facilities. 


\section{FUNDING}

The study was supported by Islamic Azad University, Rasht Branch.

\section{AUTHOR CONTRIBUTIONS}

All the authors contributed equally to all aspects of this study. D.H. - designed the paper; F.S. performed the experiments and collected the data; B.K. - wrote the paper.

\section{CONFLICT OF INTEREST}

Authors declare no conflict of interest.

\section{REFERENCES}

A.O.A.C., 1970. Official Methods of Analysis of the Association of Official Agricultural Chemists. $11^{\text {th }}$ Ed. AOAC, Washington, DC, 16-17.

Abdul Jaleel C., Gopi R., Gomathinayagam M., Panneerselvam R., 2009. Traditional and nontraditional plant growth regulators alter phytochemical constituents in Catharanthus roseus. Process Biochem. 44, 205-209.

Abdul Jaleel C., Manivavannan P., Sankar B., Kishorekumar A., Gopi R., Somasundaram R., PanneErselvam R., 2007. Psudomonas fluorescens enhances biomass yield and ajmalicine production in Catharanthus roseus under water deficit stress. Colloids Surf. B: Biointerfaces 60(1), 7-11.

AfaQ S.H., Tajuddin, Siddiqui M.M.H., 1994. Standardization of Herbal Drugs. AMU Press Aligarh, India.

Algawadi A.R., Gaur A.C., 1992. Inoculation of Azospirillum brasilense and phosphate-solubilizing bacteria on yield of sorghum [Sorghum bicolor (L.) Moench] in dry land. Trop. Agric. 69, 347-350.

AtTia F.A., SAAD O.A.O., 2001. Bio-fertilizers as partial alternative of chemical fertilizer for Catharanthus roseus G. Don. J. Agric. Sci., Mansoura Univ. 26(11), 7193-7208.

Cakmakci R., Donmez M.F., Erdogan U., 2007. The effect of plant growth promoting rhizobacteria on barley seedling growth, nutrient uptake, some soil properties, and bacterial counts. Turk. J. Agric. For. 31, 189-199.

Karlidag H., Esitken A., Turan M., Sahin F., 2007. Effects of root inoculation of plant growth promoting rhizobacteria (PGPR) on yield, growth and nutrient element contents of apple. Sci. Hortic. 114, 16-20.

Karthikeyan B., Abdul Jaleel C., Azooz M.M., 2009. Individual and combined effects of Azospirillum brasilense and Psudomonas fluorescens on biomass yield and ajmalicine production in Catharanthus roseus. Acad. J. Plant Sci. 2(2), 69-73.

Karthikeyan B., Abdul Jaleel C., Lakshmannan G.M.A., Deiveekasundaram M., 2008. Studies on rhizosphere microbial diversity of some commercially important medicinal plants. Colloids Surf. B: Biointerfaces 62, 143-145.

Karthikeyan B.N., Joe M.M., Abdul Jaleel C., Deiveekasundaram M., 2010. Effect of root inoculation with plant growth promoting rhizobacteria (PGPR) on plant growth, alkaloid content and nutrient control of Catharanthus roseus (L.) G. Don. Nat. Croat. 19(1), 205-212.

Khalid A., Arshad M., Zahir Z.A., 2004. Screening plant growth-promoting rhizobacteria for improving growth and yield of wheat. J. Appl. Microbiol. 96, 473-480.

KhattaK A.M., Ahmad I., Amin N.U., Vahid F., Rahman H.U., 2011. Effects of different amended organic media on the growth and development of Vinca rosea 'Victory'. Sarhad J. Agric. 27(2), 201-205.

ŁATA B., 2007. Cultivation, mineral nutrition and seed production of Catharanthus roseus (L.) G. Don in the temperate climate zone. Phytochem. Rev. 6, 403-411.

Luo M., Fu Y.J., Zu Y., Quan S., Mu F., Li Q., 2005. Rapid determination of 4 vinca alkaloids by reversed phase high performance liquid chromatography. Chin. J. Anal. Chem. 33, 87-89.

Magnotta M., Murata J., Chen J., De Luca V., 2006. Identification of a low vindoline accumulating cultivar of Catharanthus roseus (L.) G. Don by alkaloid and enzymatic profiling. Phytochem. 67, 1758-1764.

Maloney E.M., Fong H.H.S., Famsworth N.R., Blomster R.N., Abraham D.J., 1968. Catharanthus alkaloids XV. Isolation of vindolinine from C. lanceus leaves. J. Pharm. Sci. 57(6), 1035-1036.

Masidur Alam M., Naeem M., Idrees M., Masroor M., Khan A., Moinuddin, 2012. Augmentation of photosynthesis, crop productivity, enzyme activities and alkaloids production in Sadabahar (Catharanthus roseus $\mathrm{L}$.) through application of diverse plant growth regulators. J. Crop Sci. Biotechnol. 15(2), 117-129.

Matros A., Amme S., Ketting B., Buck-Sorlin G.H., Sonnewald U., Mock H.-P., 2006. Growth at elevated $\mathrm{CO}_{2}$ concentrations leads to modified profiles of secondary metabolites in tobacco cv. SamsunNN and to increased resistance against infection with potato virus Y. Plant Cell Environ. 29, 126-137.

Mazumdar B.C., Majumder K., 2003. Methods on Physico-chemical Analysis of Fruits. Daya Publishing House Press, New Delhi, India.

Mishra P., UniYal G.C., Sharma S., Kumar S., 2001. Pattern of diversity for morphological and alkaloid yield related traits among the periwinkle Catharanthus roseus accessions collected from in and around Indian subcontinent. Genet. Resour. Crop Evol. 48, 273-286.

O'ConNell P.F., 1992. Sustainable agriculture - a valid alternative. Outlook Agric. 21, 5-12.

Shangguan Z.P., Shao M.A., Dyckmans J., 2000. Nitrogen nutrition and water stress effects on leaf photosynthetic gas exchange and water use efficiency in winter wheat. Environ. Exp. Bot. 44, 141-149. 
Shen J., Li R., Zhang F., FAn J., TAng C., Rengel Z., 2004. Crop yields, soil fertility and phosphorus fractions in response to long-term fertilization under rice monoculture system on a calcareous soil. Field Crops Res. 86, 225-238.

SidDIQUi Z.A., 2004. Effect of plant growth promoting bacteria and composed organic fertilizers on the reproduction of Meloidogyne incognita and tomato growth. Bioresour. Technol. 95, 223-227.

Singh A., Agrawal M., 2015. Effects of ambient and elevated $\mathrm{CO}_{2}$ on growth, chlorophyll fluorescence, photosynthetic pigments, antioxidants, and secondary metabolites of Catharanthus roseus (L.) G. Don. grown under three different soil N levels. Environ. Sci. Pollut. Res. 22, 3936-3946.
Singh D.K., SRivastva B., SAhu A., 2004. Spectrophotometric determination of Rauwolfia alkaloids: estimation of reserpine in pharmaceuticals. Anal. Sci. 20(3), 571-573.

Thosar N.J., Ingle V.G., Jadhar J.C., 2005. Effect of FYM and biofertilizers on dry root and seed yield of Ashwagandha (Withania somnifera). Crop Prot. Prod. 1(2), 27-28.

VESSEY J.K., 2003. Plant growth promoting rhizobacteria as biofertilizers. Plant Soil 255, 571-586.

ZhaO X., MaO Z., Xu J., 2010. Gas exchange, chlorophyll and growth responses of Betula platyphylla seedlings to elevated $\mathrm{CO}_{2}$ and nitrogen. Internat. J. Biol. 2, 143149.

Received August 4, 2017; accepted March 8, 2018 